\title{
Marine Economics, Employment and Employability: Profiles, Professional Figures and Skills in the Reform of the Italian Code of Recreational Shipping (Code of Yachting)
}

\author{
By Roberta Caragnano* \& Giuseppe Danese
}

\begin{abstract}
The Legislative Decree of 3 November 2017, n. 229 on Code of Yachting, whose discipline is included in the legislative decree 18 July 2005, n. 171 came into force on 13 February 2018. The legislative text, which attributes equal dignity to the commercial non-profit navigation, is the result of an intense work started in 2015 when with the law delegated $n$. 167 the Government was delegated to adopt within twenty-four months (from the date of entry into force of the law) one or more of the legislative decrees for the revision and integration of the current Code (of 2005). The object of the new legislation is the competitiveness of Italian sector in the European and International context. The reference context in which the new regulatory provision is placed is, in fact, the globalised economy on which both the European Institutions and the Commission have intervened with synergic actions on the assumption of the great potentialities deriving from the economy of the sea, in its variations from the blue economy, to the blue sea to the blue growth. In this sense is central the wellbeing and prosperity of the Europe, in line with the European maritime contribution to contribute to the implementation of joint actions in the direction of international governance. The Italian Legislator has intervened in the mesh of the legal text and in the various forecasts also regarding new titles and professional profiles for boating. In the essay presented, the news on the subject will be illustrated, which impacts both on the contents and on the structure of the Code and, indirectly, likely to produce effects on the labour market both at the employment and training level. A focus will also be given to the role of education and training systems, professional qualifications and skills development in the European scenario as well as to the Italian prospects for the maritime and nautical sector and through apprenticeships, skills certification and cluster investments. The essay closes with the actions and perspectives de iure condendo on the nautical district of the Apulia Region.
\end{abstract}

Keywords: Code; Yachting; Labour market; Training; Apprenticeship

\footnotetext{
"Independent Researcher, PhD of Labour Law and Industrial Relation at University of Modena and Reggio Emilia, Member of Center for Contemporary Labour Law - CCLL of Tbilisi. Email: caragnano.roberta@gmail.com.

"President of Nautical District of Apulia, Italy. G. Danese is the author of Findings/Results chapter. Email: giu.danese@gmail.com.
} 


\section{Introduction}

The Position of the Problem: The Extent of the Code and the European Economic and Legal Framework of Reference

The legislative decree, n.229 of 3 November 2017 renewed significantly the Italian Code of Recreational Shipping (Yacht Code) whose regulations are contained in decree n.171 of 18 July 2005 - which implements the 2003/44/CE directive subsequently modified by the 94/25/CE directive - creating an independent regulating body.

The text, applying Article 1 of the law n.167 dated 7 October 2015, with which the Government was delegated to adopt within twenty-four months (from the date the law was passed) one or more of the revised and integrated decrees included in the above-mentioned code (n.171/2005), represents an important dowel within the legislative action (and not only) supporting the entire nautical chain including the development of shipbuilding and refitting.

In fact, the decree in its entirety, establishes greater protection of the public interest in general, specifically the protection of the marine environment, shipping safety, the safeguarding of human life at sea, the promotion among the new generations of marine culture, and respect and the inclusion of the disabled.

The extent of the legislative novelty - which encompasses the various requests for integration and modification made by Ucina Confindustria Nautica together with Assomarinas and Assonat Confcommercio (tourist ports) and Confarca (nautical schools), Assilea (leasing), and Federazione Vela - is aimed at rendering the Italian sector more competitive in the European and International market. With this in mind, it is important to consider the forecasts for the telematic registration of boats and digital information for boaters including ways to simplify the administrative procedures.

The new regulatory provisions fall in the context of a globalised economy in which many European institutions and indeed the Commission itself have introduced coordinated actions based on the enormous potential of the marine economy. The declinations blue economy ${ }^{l}$, blue sea or blue growth illustrate that the marine economy is regarded as a driver in the well-being and prosperity of Europe and the decree falls in line with the integrated European maritime policy dedicated to the realisation of coordinated efforts working towards the idea of an international governance.

In 2010 the Commission ${ }^{2}$ had already anticipated a strategy for sustainable maritime and coastal tourism, highlighting on the one hand the need for a concerted effort in favour of a coordinated approach to initiatives on the theme of tourism, and on the other hand, the need for a definition of a new framework for action to reinforce competition and the capacity for sustainable growth in the sector. This strategy was subsequently promoted in the 2012 communication,

\footnotetext{
${ }^{1}$ This also includes the alignment between blue growth and green growth as also indicated, in the seventh program of environmental action. European Parliament and Council of the Eureopean Union (2013).

${ }^{2}$ See European Commission (2010).
} 
Crescita blu opportunità per una crescita sostenibile dei settori marino e marittimo. (Blue Growth opportunities for marine and maritime sustainable growth $)^{3}$. According to this communication, the sea and the coast represent engines for economic growth where coastal communities, due to their geographic conformation open to the outside and their tradition become hotbeds for new ideas and sources of inspiration for innovation encompassed in an ample vision of the direction of the so-called Blue Growth. Within the European Strategy 2020 this growth can increase international competitiveness within the EU, not only developing new sources of growth respecting and protecting biodiversity and the marine environment, but also creating new jobs whilst maintaining marine ecosystems and healthy coastal areas.

In the Commission Communication, A European Strategy for more Growth and Jobs in Coastal and Maritime Tourism, COM(2014) 86 final $^{4}$ - in the wake of the Parliament's report on blue growth of $2013^{5}$ - a series of actions were outlined in order to breathe life into the sector and help the development of a sustainable tourism in coastal destinations focusing on the involvement of the Commission, member states, local and regional authorities, private operators and other stakeholders, taking into account the presupposition and the knowledge that the demand for tourism is exposed to great fluctuations determined by changing economic, financial and political circumstances which affect the whole chain including the nautical sector.

Similarly, the Report on the Blue Growth Strategy: Towards more sustainable growth and jobs in the blue economy SWD (2017)128 final of 31 March $2017^{6}$ outlines a new European strategic approach that includes eco- sustainability and the profitability of the production processes as a possibility for the development of a whole series of activities connected to the sea, including tourism by means of cruises, pleasure boats and maritime traffic.

\section{Findings/Results}

\section{The Economy of the Sea and Employability: The Studies and European Data}

The job market as a whole is changing and in recent years, in part due to the effect of an acceleration determined by the Crisis as well as a globalised economy, it has undergone transformations that have redrawn the reference markers. As Casino has concisely observed, "In a certain sense, the breaking down of special and temporal confines in the organisation of the workplace, the intensification of occupational and geographical mobility; the diffusion of a more agile way of working without the necessity of a physical presence in a workplace, implies the

\footnotetext{
${ }^{3}$ See European Commission (2012).

${ }^{4}$ European Commission (2014b).

${ }^{5}$ European Parliament (2013).

${ }^{6}$ European Commission (2017a).
} 
rejection of the idea of a company as a closed system and introduces the diffusion of work processes within the territory" "

According to data from Cede fop (European Centre for the Development of Vocational training), in $2025,44.1 \%$ of employees will perform a highly qualified job, compared to $41.9 \%$ in 2010 and $36.5 \%$ in 2000 . The elementary professions will register a constant increase from $9.8 \%$ in $2000,10.2 \%$ in 2010 to $11.2 \%$ in 2025.

To be more exact 'between now and 2025, more often than not, the available jobs at all levels of expertise will be those not easily substituted by technology, by changes in the workplace and by outsourcing. These are jobs which require thinking, communication, organisation and decision-making, 8

Nevertheless the marine economy is significant in terms of the growth of "jobs", taking into account that an analysis of of potential employment patterns in Europe $^{9}$ has revealed five areas of value as possible sources of sustainable and occupational growth in the blue economy sector: Blue energy, aquaculture, coastal and cruise ship maritime tourism, marine mineral resources and blue biotechnology. It is also possible to add further to these areas, based on the systems already in place. The opinion of the writer is that recreational shipping is one such possibility which would create a new job rush allowing the blue economy to increase its potential as a sustainable growth area based on the supposed need and possibility to put in place policies and actions which can be shared by the various levels of authority and the stakeholders, in order to activate drivers of change capable of creating the just conditions to ensure a rapid expansion of the economy within the context of a globalised Europe.

According to estimates (data and research), however, the scenario could change before 2010 due to presence of new sectors capable of influencing the number of jobs being created which would imply further investment to ensure sustainable growth.

According to the theory of intersectional interdependence ${ }^{10}-$ which determines how much productive input is bought by each sector of the economic system - statistically measured using input-output tables, elaborated nationally by ISTAT, an estimate regarding the activation capacity of the sea has revealed that for every euro produced in this area, another euro is activated in the general economy. The data released by the European Commission in its report on Blue Growth Economy ${ }^{11}$ indicates that the blue economy generates a gross added value of about 500 billion euro per year employing 5.4 million people in the European Union; 97\% of whom are employed in 5 important sectors: navigation, non-living resources (petroleum and gas), living resources (fishing and aquaculture), and coastal tourism. Of particular importance is the assessment of feasibility and added value of the Iniziativa sulla blue economy nel Mediterraneo occidentale dated

\footnotetext{
${ }^{7}$ Casano (2017b)

${ }^{8}$ Cedefop (2013).

${ }^{9}$ See the quoted communication of the European Commission (2012).

${ }^{10}$ See Eurostat (2001) and ISTAT (2006) for a methodical description of the mentioned input-output tables.

${ }^{11}$ European Commission (2017a).
} 
January 2017, which upholds maritime transportation, maritime tourism, recreational activities and fishing as being currently the most important economic activities in Western Europe acting as an employment engine.

The OECD estimates that from 2030 onwards, the sea or so-called "ocean" industries will have the potential to overtake the global economy as a whole, both in terms of added value and employment, providing a global output of 1.3 trillion euros. The prospective for doubling this figure before 2030 is possible.

To this macroeconomic scenario, the actions supporting small and mediumsized businesses should be mentioned. These actions are connected to the local context both geographically and in sector-specific terms, producing a positive domino effect on energy policies (green businesses and green jobs) and equally on employment both in terms of human capital (especially young people) and an exchange of good practice emerging from the new sustainable economies.

Innovation and the sharing of knowledge are two such drivers which help to manage the generational changes in the workplace and increase its ability to face crises and short-term shocks.

The European Commission sees the creation of jobs as an essential element of research and development for a sustainable Blue Growth, as in the Bluemed project $^{12}$. This conclusion is born from the belief that the double challenge is represented by the key sectors of tourism, transport and fishing, which require innovation and diversification in order to be competitive and sustainable whilst ensuring the creation of quality employment in areas where activity and the emerging value system requires more support to attract investment and, consequently, potential development.

\section{Discussion}

\section{News from the Recreational Shipping Code on Professional Titles}

The legislative decree no. 229 of 3 November 2017 contains various predictions concerning new professional titles and profiles within recreational shipping which affect both the content and structure of the Code and, indirectly may also have an effect on the labour market both in terms of employment and constitution.

The legislator primarily intervened in Article 27 with the introduction of the simplified title of second-class recreational sailing officer in the role of recreational shipping cover services. In doing so a link was created between the IMO certificate, the STCW 78/95 standard (Standards of Training, Certification and Watchkeeping for Seafarers) and introductory school education, creating a

\footnotetext{
${ }^{12}$ Bluemed - which aims to update Bluemed Sria, the strategic agenda on research and innovation, as well as the development of an operational project for the activation of joint initiatives together with the gradual and systematic involvement of the non-EU states of the Mediterranean and the realisation of pilot projects - is an important initiative of the European Commission within the Quadro Horizon 2020 Program. This has seen an investment of 3MEuro and reenters in actions of support for the same political initiative for research and innovation in the marine-maritime sector of the Mediterranean Region.
} 
simplified title for recreational shipping and recognizing that prior to the changes there had been little communication between this title and other professional titles. The endeavour was to align the national regulations with those in Europe, following the initiative started in 2005.

The new order will in itself have an effect on the decree of the Ministry of Transport and Infrastructure dated 10 May 2005, that is no. 121 which determines the institution and the organisation of professional titles ${ }^{13}$ in recreational shipping, that is the determining of the professional figures that work on the units and ships used in rental activities, exclusive and not. The area covered by the Regulation covers, in fact, all personnel boarded on recreational ships for rental use, on ships destined exclusively for tourist rentals as described in article 3.1 of law no. 172 of 8 July 2003 and the personnel who carry out paid activity on recreational vessels.

All of this does not change the legislation regarding the issue of ship licenses for the use of recreational vessels, covered by article 4 of decree no. 431 issued by the President of the Republic dated 9 October 1997. Likewise it is for the current legislation that requires all shipping personnel involved in recreational shipping to be enrolled on the register of First Class Seafarers as well requiring the navigation license. The general provisions for the registration of seafarers are applied as described in Book 1, Title IV, Chapter 1 and 2 of the Regulation for the carrying out of the Navigation Code, approved by decree no. 328 of the President of the Republic dated 15 February 1952. It states that those who work aboard commercial units must be enrolled and protected by the necessary forms of insurance and social security.

With regard to the simplified title another decree should be noted: comma 2 of article 27 refers the modification of article 2, comma 3 of law no. 17 dated 8 July 2003 to a decree by the Ministry of Transport and Infrastructure together with the Ministry of Education, Higher Education and Research in order to individuate the requirements for the carrying out of cover services in recreational shipping and ensure full compatibility between the various professional profiles of the sector regarding the newly- introduced changes to the law.

The legislative decree no.229 dated 3 November 2017, therefore realises the contents of the delegated law, in line with European provisions with the aim of improving the conditions of effective competition within the scope of the European Strategy for greater growth and employment in coastal and maritime tourism as identified in Communication COM (2014) 86.

This serves as valuable support for a sector, that of recreational shipping, that has had to face up to a number of difficulties throughout the years related to differences between member states with respect to mandatory qualifications and on-board safety equipment. These have acted as a limit on mobility and access to the job market, which has frequently conditioned the trans boundary development of the nautical sector and as a consequence due to a domino effect has also had a negative effect on the employment situation in the nautical field.

\footnotetext{
${ }^{13}$ The regulation is quoted in article 3 of the quoted law 8 July 2003, no.173, and explains the use of ships exclusively rented for tourist purposes.
} 


\section{The New Professional Figures: Recreational Mediator and Sailing Instructor}

Article 33 of Legislative Degree no.229 of 3 November 2017 introduces the Capo II- bis regarding professional figures into the recreational shipping code (legislative decree no. 171/2005), creating the professional roles of recreational mediator and sailing instructor as outlined in the following articles: 49-III, 49-IV, 49-V and 49-VI.

The first, separate from that of Maritime Mediator, will perform advisory functions for the conclusion of contracts regarding construction, trade, leasing, renting, loans, mooring and the financial leasing of recreational craft. The second description regards the professional teaching of sailing techniques, also in a nonexclusive and non-continuous way in all their specialisations and practised in all masses of water whether the sea, lakes or inland.

With regards to the specific aspects of the professional figure of the recreational mediator, it is the writer's opinion that his is a hybrid position, borrowed in part from the civil code both in its definition and for some applied profiles. The legislator himself mentions this in subsection 6 of article 49-III in the part, "subject to the provisions of this article and article 49-IV of this code, recreational mediators adhere to the measures outlined in article 1754 and following the civil code." In part the job description is borrowed from the legislation relating to the profession of maritime advisor in particular decree no. 135 dated 4 April 1977, without prejudice to the exclusive development of the activity as provided by subsection 2 of article 49-III and therefore following the rules of recreational shipping code.

The mediator can perform related or instrumental activities and carry out his professional activity without being bound to any other parties by collaboration, full-time employment, representation or any other work relationship which could limit independence.

The activity must be reported to the Chamber of Commerce, Industry, Artisanship and Agriculture via a "start of activity" certificate (SCIA) which must be presented to the single front office of the municipality responsible for the territory, which after verifying that the necessary criteria are met, will register the activity either in the business register if it is a commercial venture or in the appropriate section of the list of economic and administrative news (REA) if it is otherwise defined.

The criteria required to carry out the profile of recreational mediator are as follows: citizenship of the European Community; minimum age of 18; honour ability requirements as cited for maritime mediators contained in act no. 478 of 12 March 1968, having fulfilled the obligation of education, as described in Article 1, subsection 622 of Act no. 296 of 27 December 2006; having attended a suitable theoretical and practical course and passed the relative examination (apart from maritime mediators indicated in legislation no.478 of 12 March 1968); being in possession of an insurance policy covering civil liability for damages caused during activity by own or third party conduct, according to the law. Other requirements include not having been declared a habitual, professional or treacherous offender, not having been subjected to personal safety or preventative 
measures, not having been sentenced to imprisonment except in the case where rehabilitation measures have been introduced as cited in legislative decree no. 159 of September 6, 2011.

The course required to become a mediator is organised every year by the regional authority, under payment by the participant of a fee commensurate with the costs incurred by the local authorities in organizing the said course. The fee is communicated every three years by way of a decree of the Ministry of Transport and Infrastructure, in communication with the Ministry of Finance, and with the prior agreement of the unified state-region conference. In fact, the statutory provision is of an orderly nature and does not involve minors entering and new or greater charges for public finance.

Subsection 6 of Article 49-IV regards disciplinary measures (annotated and registered for extract in the REA) for the violation of professional ethics, or to be more precise, the behavioural norms locally established and recorded by the Chamber of Commerce, Industry, Artisanship and Agriculture. Subsections 7, 8, 9 and 10 define cases for suspension and subsection 11 defines expulsion from the profession.

The professional figure of the sailing instructor, is regulated by articles $49-\mathrm{V}$ and 49-VI of the legislative decree no. 171 of 18 July 2005 (Recreational Shipping Code) introduced by Article 33 of legislative decree no. 229 of 3 November 2017. The profile is defined as " he who teaches professionally the techniques of sailing in all its specialisations also in a non-exclusive and non-continuative manner, individuals or groups of people, in any type of vessel, in the sea, lakes or internal waterways."

Professional practice is reserved for candidates registered on a special list maintained by the Ministry of Transport and Infrastructure. The fees both for the fulfilment of the administrative obligations and the inclusion on the list will be charged to the individual at a cost which allows the adequate maintenance of the said list by the Ministry.

The collection of the aforementioned fees (as foreseen in Subsection 5, Article $49-\mathrm{V}$ ) is similar to that applied to the profession of recreational mediator, but in this case rather than be collected by regional authorities, the revenue "enters into the balance of the State where it is re-assigned, under decree of the Ministry of Finance, to the relevant workings of the Ministry of Transport and Infrastructure in order to cover the costs of the management of the said list".

The sailing instructor is subject to similar legislative criteria: citizenship of the European Union; minimum age of 18; having fulfilled the obligation of education, Article 1; subsection 622 of Act no. 296 of 27 December 2006; not having been declared a habitual, professional or treacherous offender; not having been subject to personal safety or preventative measures; not having been sentenced to imprisonment except in the case where rehabilitation measures have been introduced as cited in legislative decree no. 159 of September 6, 2011; having residence or domicile or a fixed address in a municipality of the Italian Republic. Other requirements are: a license for teaching the basic techniques of sailing issued by the Navy, the Italian Yachting Federation or by the Italian Naval League which follows the guidelines laid down by the national system of sporting 
instructors by CONI (Italian Olympic Committee) and the European Qualification Framework; a certificate of psychophysical fitness on the basis of the requirements stated in Article 5 of the decree-law no.663 of 30 December 1979. The sailing instructor should also be in possession of an insurance policy covering civil liability for damages caused during activity by own or third party conduct, according to the law.

The enrolment on the said list is valid for six years and must be renewed every three years under the condition of psychophysical fitness and the attendance of professional refresher courses organised by the Navy, the Italian Yachting Federation or by the Italian Naval League. Such courses will be at the expense of the individual concerned and are equal to the costs incurred for the management of the aforementioned parameters regarding the recreational mediator.

The disciplinary procedure for the sailing instructor is similar to that for the recreational mediator even if they differ in terms of profile and job requirements. The only inherent difference is that an eventual exclusion is considered definitive in severe cases where an individual is unable to complete the activity for "extremely serious violations that create a situation of non- compatibility with the professional activity in case" and where " the individual's behaviour has seriously undermined his own reputation and that of his profession". Sub-section 9 of Article 49-VI covers the cases where the Legislator has deemed that mandatory exclusion should be applied.

\section{Labour Law Perspectives under Iure Condendo}

The theme of labour law and the job market is even more delicate if we take into consideration the new profiles introduced by the Legislator of the reforms (recreational mediator and sailing instructor) within the context of a more wideranging regulatory-economic scenario which encourages legal reflection on the current contractual situation regarding professional profiles within recreational shipping and the more appropriate viewpoint of iure Condendo ${ }^{14}$ which takes into consideration the specific characteristics of the nautical sector.

The legislator of the reform seems to outline this concept with regards to the recreational mediator, by applying a definition which represents a hybrid between the norms of the civil code ("the disciplines laid out in Article 1754 and onwards of the civil Code should be applied to the profile of recreational mediator apart from the provisions of this article and article 49-IV of the present article", as also in subsection 6 of Article 49-III), the provisions laid down for maritime consignor in law no. 135 of 4 April 1977 not withstanding the separate activity laid down in subsection 2 of Article 49-III, and the norms of the Recreational Nautical Code.

This last consideration with the discipline contained within the Code, appears to lead in the direction outlined taking into consideration a special legislation (that

\footnotetext{
${ }^{14}$ Regarding the application of legal requirements for shipping personnel and the new professional figures of mediator and sailing instructor and profiles connected to health and safety at work, see Caragnano \&.Danese (2018)
} 
of recreational shipping) within the context of already specialised legislation (that of rights of navigation), recognizing its strong interdisciplinary character with regards to private, commercial and labour laws and not only. In the light of new economic scenarios this reflects the aim of the Legislator to evaluate a new and essential path together with the stakeholders in creating a starting point for a concrete intervention which could render the Italian sector more competitive in the European and International scene. From the perspective of de Iure condendo the new norms considered by the Legislator with regards the aforementioned professional figures together with the simplified job descriptions with reference to the cited regulations, require the evaluation of a labour contract that takes into consideration the specific needs of the nautical and recreational shipping sectors.

It is my view that a starting point in balanced governance has been recognised in the agreement signed on the 28 February 2018 between Confindustria and Cgil, CISL, Uil (Italian trade unions) covering the content and direction of industrial relations and collective bargaining which concentrate on the firm action needed to " strengthen measures to support an independent, innovative and participatory trade union model, which upholds the competitiveness of the sector and of the production chains, as well as its values and quality of work, and favours also via the spread of second-level bargaining, the ongoing transformation processes and the virtuous connection between innovation, productivity and wages."

\section{Conclusion}

Instruction and Training Systems, Professional Qualifications and Skills Development in the European Scenario

The recent provisions regarding professional profiles in recreational shipping lead us to a more general reflection than focusing only on employment prospects, in particular regarding young people. The study carried out by EASME/DG Maritime Affairs and Fisheries, entitled Study supporting a possible network of maritime training academies and institutes in the Mediterranean Sea Basin ${ }^{15} 14$ which supports the idea of integrated action and networking between maritime academies and training institutions in the Mediterranean area, has demonstrated how complicated and fragmented the current situation is. Its main message is that the maritime industry should be more active in demonstrating to young people the diversity of careers available within the maritime economy above all by collaborating with schools on the subject of professional training.

The employment situation in the maritime sector of the western Mediterranean area is particular. An example of this: whilst on the one hand youth unemployment is between $14 \%$ and $58 \%$, on the other hand the companies working within the maritime sector are not always able to fill the professional roles or cover the skills required ${ }^{16}$.This shows that there is a gap between supply and demand which is often determined by a lack of communication between the

\footnotetext{
${ }^{15}$ The study EASME/DG Maritime Affairs and Fisheries (2016).

${ }^{16}$ Consult the European Commission (2017b).
} 
businesses concerned and the educational system including schools, universities and also ITS and post-degree training.

The commission in collaboration with training institutions within the maritime sector, intends therefore to face this situation of imbalance within the framework of Sviluppo e della circolazione delle competenze to realise the following ideas: promotion and creation of networks and exchanges between maritime, port and logistic academies and institutes; the sensitisation towards the maritime professions by making them more appealing to young people; the creation of initiatives to favour the balance between demand and job offers for multimodal transport of goods, in supply chains and in infrastructure; harmonisation of the functions and existing skills for the management of questions regarding movement within the region and promotion of the most efficient way to achieve circular migration.

Potential sources of funding to consider include: the European fund for maritime affairs and fishing (FEAMP) ${ }^{17}$ the initiative promoted by the FAO in favour of Blue Growth which aims to assist small insular and developing states to use their water resources in a sustainable manner, projects financed by the European Social Fund (FSE), l'Erasmus+ for university students and funds released by the various member states ${ }^{18}$. The priority should be the coordination of the various programs and the concrete initiatives both realised and those still in course within the Mediterranean region including the action plan for the Atlantic and the EU Strategy for the Adriatic and Ionian region as well as the quoted initiatives BLUEMED and PRIMA ${ }^{19}$.

The concept of a sustainable economy is to be considered in a systematic way in relation to the politics of employment which acknowledges a development that enables an occupational growth above all for young people favouring politics and measures which create both growth and competitiveness.

This concept is reaffirmed by the European Commission in its annual report on employment and social development (ESDE), published in the summer of 2017, which highlights the importance of investment in people and the need to

\footnotetext{
${ }^{17}$ This fund id one of five European structural and investment funds (SIE funds) which integrate with each other, with the aim of promoting a recovery based on growth and employment in Europe. FEAMP is one of the main sources of support for the new common politic on fishing (PCP) and according to the objectives defined in the program for 2014-2020, the aim is to improve the social, economic and environmental sustainability of the seas and coasts in Europe by supporting local projects, companies and the community in loco. With this in mind the fund finances projects that create new jobs and improve the quality of life in European coastal regions, helping the coastal communities to diversify their economies and support the fishing community in a transition towards sustainable fishing.

${ }^{18}$ See Camera dei Deputati XVII, Legislation (2017).

${ }^{19}$ The program PRIMA, an acronym for Partnership for Research and Innovation in the Mediterranean Area, sees an ample partnership between member states of the European Union (France, Spain, Italy, Portugal, Greece, Malta, Cyprus, Germany) and non EU countries of the Mediterranean (Egypt, Jordan, Lebanon, Turkey, Morocco, Tunisia, Algeria and Israel) with the aim of improving the health and well-being of the populations of the Mediterranean area encouraging economic growth and long-term stability. The MUIR, for Italy, will actively participate in an operational direction that will see 2018 as a Launchpad for the first tenders financing partnerships of research and innovation between institutions and companies from the two sides of the Mediterranean.
} 
give them the opportunity to take advantage of quality work opportunities, which in turn represents the central theme of the Nuova agenda per le competenze per l'Europa, with the aim of sustaining the skills of the citizens in order to prepare them for an ever-changing workplace.

The invitation included in the report made by the European Commission ${ }^{20}$ to "work in close contact with Cedefop to estimate more accurately to anticipate the future needs in terms of skills and adapt them to the marketplace" is highly relevant, as is the need to improve the understanding and comparability of the different qualifications that exist in the different member states. With this in mind the proposal to review and further develop the EQF (European Qualifications Framework) ${ }^{21}$ has been received favourably, acknowledging the cooperation between the member states and all interested parties and encouraging increased coherence between the examining bodies of the EU, that is, EQF, ECVET (European Credit System for Vocational Education and Training) ${ }^{22}$ and EQAVET (European Quality Assurance in Vocational Education and Training). Similarly important is point 151 of the aforementioned report in which the Commission " favourably receives the initiative created to introduce a system of traceability of graduates in order to offer a more pertinent approach based on solid data to elaborate study programs and job offers and asks for a similar system to regroup high school graduates" 23 .

The invitation is to proceed with an analysis of qualification systems in order to propose an adaptation to satisfy the needs of emerging professional titles including the organisation on an annual basis of a "European Forum of Skills" which would allow the authorities concerned, the training institutions, professionals, students, employers and workers to exchange the best practices in terms of forecast, development and convalidation of skills" ${ }^{24}$.

\footnotetext{
${ }^{20}$ European Parliament (2017).

${ }^{21}$ Following the recommendations of the European Parliament and Council on the constitution of a European Framework for Qualifications (EQF) for permanent learning (Gazzetta ufficiale dell'Unione Europea 2008/C 111/01) regarding the constitution of the EQP the member states are invited to "bring their national systems of qualifications to the same level as the EQF, and where it is opportune to develop national frameworks for qualifications in accordance with with national laws and procedures."

${ }^{22}$ Following the recommendations of the European Parliament and Council of 18 June 2009 on the creation of a European Framework for the guarantee of quality of instruction and professional formation which acts as a system of transferal of credits to facilitate the acknowledgement and transfer of results and abilities by way of certification. This covers all non-academic qualifications whilst for academic titles the ECTS (European credit transfer and accumulation system). The ECVET system is not mandatory for the different systems but is more of a gradual development to be implemented on a voluntary level by the various European countries, taking into account local and national, as well as sectorial regulations (definition of ISFOL). ECVET integrates and completes existing systems developed within the EU in favor of mobility of those gaining qualifications, such as EUROPASS, the European Card of Quality for Mobility (EQCM) and the European System of Accumulation and Transfer of Credits (ECTS, hereby connecting instruction and professional formation in secondary schools. See Liguoro (2012).

${ }^{23}$ Point 151 of the Resolution of 14 September 2017 on a new skills agenda for Europe (2017/2002(INI)):

${ }^{24}$ Point 155 of the Resolution of 14 September 2017 on a new skills agenda for Europe (2017/2002(INI)).
} 
The growth of the Blue Economy, in fact, requires personnel who are ever more qualified with remarkable skills capable of applying the latest technology in engineering also in other disciplines, "with reference to the Leadership 2020 report for operators in the naval construction industry of the EU, the growing complexity of products has brought about the demand for highly qualified personnel. A large part of the sector is affected by a lack of qualified personnel, a fact which obstructs growth" ${ }^{, 25}$.

The Italian Forecast for the Maritime and Nautical Sector: Apprenticeship, Skills Certification and Investment in Clusters

With the aim of realizing a community for knowledge and innovation $(\mathrm{KICs})^{26}$ for the Blue Economy ${ }^{27}$ that unites the main parties interested from the world of institutions, public authorities, research, business and instruction around a triangle of knowledge (training, research and innovation), there is a strategic need to invest in young people, creating a network which includes the world of business to create fertile ground also in terms of employment.

As observed in the doctrine, it all comes down to " the sudden outdating of technical-professional skills, the birth of new crafts and the changes in the skills profiles needed to control technology that confirm the crucial role played by the development of skills in a modern system of protection ${ }^{28}$. For this reason the focus is on a new theoretical approach to the "transitional work places" 29.

The recourse to apprenticeship ${ }^{30}$, an instrument of great potential and opportunity as well as being a strategic means to create a dialogue between schools and work ${ }^{31}$, in the current Italian economic-legislative scenario, is something to be valued and implemented in a sector such as the nautical sector

\footnotetext{
${ }^{25}$ See European Commission (2014a).

${ }^{26}$ The Community of Knowledge and Innovation (KICs) introduced via a European regulation of 2008, represents the main working medium of the European Institute of Technology (EIT), created with the idea of contributing to competitiveness and a sustainable economic growth, by way of strengthening the capacity of the EU and member states within the context of the 'triangle of knowledge'.

${ }^{27}$ So far three KICs have been launched on the themes of Energy, Climate Change, and Technology of Information and Communication (ICT) and via the Communication COM (2014) 254 final/2 "Innovation in the Blue Economy: realizing the potential of our seas and oceans for jobs and growth, COM (2014) 254 of 8 May 2014, the Commission announced that it will evaluate the creation of a CCI on Blue Economy in 2020.

${ }^{28}$ See Casano (2017b). The theme is developed in the assay by the same author Casano (2017c)

${ }^{29}$ Consult also Schmid (2011) whose analysis of the transitional workplace, and in particular institutional agreements on the theme of "active politics of safety" in which legally guaranteed social rights favor the participation at a decision-making level in terms of work and employment as well as to share equally results and risks; Rogowski (2008) at 200; Auer \& Gazier (2008); Schmid \& Gazier (2002); Schmid (1998).

${ }^{30}$ The Apprenticeship Institute has been recently modified by the Legislator and there is ample literature on this topic. For a general overview of the institute through its various changes, see Carinci (2002), for a more recent view Luciani (2016); Tiraboschi (2011); S. Fagnoni \&Varesi (2016); Fagnoni \& Varesi (2015); Ciucciovino (2012).

${ }^{31}$ To compare the situation with other European countries where the apprenticeship is a favored channel for employment, see: Ryzha (2015).
} 
where skills are often learnt outside of the coded and systematic circuits of standard training systems. This leads to a need to integrate levels of higher education with forms of knowledge acquired via periods of apprenticeship ${ }^{32}$.

To this aim, it is necessary to activate initiatives, sometimes also experimental, of promotion and support that allow the development of valid models for and "bridges" between schools and businesses. Investment in young people and their education through school, university and professional development, that valorises the skills obtained, represent an asset in which to invest in order to create polyhedral professional figures capable of working, adapting and moving in an ever more fluid workplace ${ }^{33}$.

Apulia, with the draft law n. 167 of 13 September $2016^{34}$, which modifies the regional law no. 131 dated 22 October 2012 (Norme in materia di formazione per il lavoro), has introduced an ad hoc regulation that realises the promotion of apprenticeship contracts in the fields of excellence within the economic and entrepreneurial system of Apulian production and technology districts, with the aim of valorizing the human worth of young people. The nautical industry is one such area. This innovative provision found in Article 2 of the draft law, consents the opening of the way for a series of initiatives included in territorial pilot schemes which based on a survey of professional and training requirements, taking into account the anticipated needs and skills required by the workplace and the nautical business sector, allows the structuring of a series of initiatives aimed at employment implementation via apprenticeship contracts and/or valid programs of school/work experience ${ }^{35}$.

The transferability and skills certification, acquired in formal contexts take on a central importance and a turning point in our labor market.

Another important point in a prospect of development, competitiveness and employment, are the investments in the cluster of the Blue Tech Nautica area, where companies, suppliers and closely interconnected institutions able to accompany and guide the development of various branches of nautical technology uniting with technological innovations, the so-called know-how Made in Italy with which many Italian regions are already working.

The study of maritime clusters dated 2015, Study on Maritime Clusters in the Mediterranean and Black Sea ${ }^{36}$, has revealed that a third and a half of all economic marine activity in the Mediterranean and Black Sea is found precisely in these formal and informal clusters. This confirms that such platforms of intersect oral and multi-level cooperation can be a powerful means to stimulate innovation, growth and employment.

\footnotetext{
${ }^{32}$ On apprenticeships and the opportunity to create valid programs of instruction and training see Cedefop (2017),

${ }^{33}$ On the topic of "fluid" workplaces consult Brollo (2012); Canavesi (2017), Mercati del lavoro e operatori private, Giappichelli, 2017. For a European overview, see: De Backer, Desnoyers-James \& Moussiegt (2015).

${ }^{34}$ At the moment of print the draft law has been approved by the competent board commission and isawaiting discussion in court.

${ }^{35}$ On this theme the most recent view is Massagli (2016); Massagli (2017).

${ }^{36}$ European Commission (2015).
} 
The approach centered on the role of maritime clusters together with technological clusters and scientific research as used in Friuli Venezia Giulia, which provides an important contribution also in terms of transferal of technology to the nautical and naval sectors, represents in a systematic view of the situation, a method of development at both a local and national level taking advantage of the structural funds 2014-2020, bringing together trans frontal countries and Mediterranean partners in a logical network.

\section{References}

Auer, P. \& B. Gazier (2008). 'Flexicurity as a Policy Agenda' in CESifo DICE Report, 2008, vol. 6, n. 4, 3-8

Bertagna, G, Casano, L. \& M. Tiraboschi (2012). 'Apprendimento permanente e certificazione delle ompetenze' in M. Tiraboschi, M. Magnani (eds.), La Nuova Riforma del Lavoro, Commentario alla legge 28 giugno 2012, n. 92 recante disposizioni in materia di riforma del mercato del lavoro in una prospettiva di crescita, Giuffè.

Brollo, M. (2012). 'Il mercato del lavoro postmoderno', in $A D L, 863$.

Camera dei Deputati XVII Legislatura (2017). Iniziativa per lo sviluppo sostenibile dell'economia blu nel Mediterraneo occidentale (COM(2017)183), Documentazione per le commissioni esame di atti e documenti dell'UE, 13 giugno 2017, n. 88.

Canavesi, G. (2017). Mercati del lavoro e operatori privati.Giappichelli.

Caragnano, R. \& G. Danese (2018). 'La riforma del codice della nautica da diporto: titoli semplificati, personale navigante e nuove figure professionali tra semplifcazioni, sicurezza e competitività' in $D P L$, Ipsoa.

Carinci, F. (2002). 'E tu lavorerai come apprendista (L'apprendistato da contratto "speciale" a contratto "quasi-unico")', WP CSDLE "Massimo D'Antona".IT $145 / 2012$.

Casano, L. (2017a). 'Le transizioni occupazionali nella nuova geografia del lavoro: dieci domande di ricerca' in Bollettino ADAPT, 27 febbraio 2017, n. 8.

Casano, L. (2017b). 'Le transizioni occupazionali nella nuova geografia del lavoro: dieci domande di ricerca' in Nòva La grande trasformazione del lavoro, 23 febbraio 2017, Il Sole 24 ore e ADAPT.

Casano, L. (2017c). La riforma del mercato del lavoro nel contesto della "nuova geografia del lavoro, WP CSDLE “Massimo D'Antona”.IT - 338/2017 e in DRI, 2017, n. 3, 634-686.

Cedefop (2013), Nota informativa. Verso la ripresa: tre scenari relativi alle competenze e al mercato del lavoro per il 2025, 2013, 2.

Cedefop (2017). Apprenticeship review ITALY. Building education and training opportunities through apprenticeships. Thematic country reviews, dicembre 2017.

Ciucciovino, S. (2012). 'Il nuovo apprendistato dopo la legge di riforma del lavoro del 2012' in Riv. it., dir. lav., I, 695.

De Backer, K., Desnoyers-James, I. \& L. Moussiegt (2015), Manufacturing or Services That is (not) the Question. The Role of Manufacturing and Services in OECD Economies, OECD Science, Technology and Industry Policy Paper, 2015, n. 19.

EASME / DG Maritime Affairs and Fisheries (2016), Study supporting a possible network of maritime training academies and institutes in the Mediterranean Sea basin, Maggio 2016. available at the following link: https://webgate.ec.europa.eu/maritime forum/sites/maritimeforum/files/Maritime\%20Academies\%20- 
\%20Final\%20Report\%20and\%20annexes_template\%20EC_0.PDF

European Commission (2010). Communication from the Commission to the European Parliament, the Council, the European Economic and Social Committee and the Committee of the Regions, [Europe, the world's No 1 tourist destination - a new political framework for tourism in Europe] $\operatorname{COM(2010)~} 352$ final http://eurlex.europa.eu/legal-content/IT/TXT/?uri=celex\%3A52010DC0352

European Commission (2012), Blue Growth opportunities for marine and maritime sustainable growth, COM/2012/0494 final in the the study on "Blue growth" by ECORYS, Scenarios and drivers for sustainable growth from the oceans, seas and coasts. ECORYS, 2012 https://webgate.ec.europa.eu/maritimeforum/content/2946, available at https://eur-lex.europa.eu/legal-content/EN/TXT/PDF/?uri=CELEX: 52012DC0494\&from=EN

European Commission (2014a). Communication from the Commission to the European Parliament, the Council, the European Economic and Social Committee and the Committee of the Regions, Innovation in the Blue Economy: realising the potential of our seas and oceans for jobs and growth, $\operatorname{COM(2014),~available~at:~http://eyr-~}$ lex.europa.eu/procedure/EN/1041945

European Commission (2014b). The quoted Communication from the Commission to the European Parliament, the Council, the European Economic and Social Committee and the Committee of the Regions, $\operatorname{COM}(2014) 86$ final is available at: https://eur-lex.europa.eu/LexUriServ/LexUriServ.do?uri=COM:2014:0086:FIN :EN:PDF

European Commission (2015). Maritime Forum. Study on Maritime Clusters in the Mediterranean and Black Sea. At https://webgate.ec.europa.eu/maritimeforum/ en/node/3648

European Commission (2017a), Commission staff working document, Report on the Blue Growth Strategy. Towards more sustainable growth and jobs in the blue economy, SWD (2017) 128 final https://ec.europa.eu/maritimeaffairs/sites/maritimeaffairs/ files/swd-2017-128_en.pdf

European Commission (2017b), Communication from the Commission to the European Parliament, the Council, the European Economic and Social Committee and the Committee of the Regions $\operatorname{COM}(2017) 183$ final, Initiative for the sustainable development of the blue economy in the western Mediterranean \{SWD(2017) 130 finall.

European Parliament (2013), Report Plenary sitting on Blue Growth: Enhancing sustainable growth in the EU's marine, maritime transport and tourism sectors] 2012/2297(INI)), A7-0209/2013- 2012/2297 (INI)) is available at http://www.Eu roparl.europa.eu/sides/getDoc.do?type=REPORT\&reference=A7-2013-0209 \&language $=\mathrm{EN}$

European Parliament (2012), Report Plenary sitting on Blue Growth: Enhancing sustainable growth in the EU's marine, maritime transport and tourism sectors 2012/2297(INI)), A7-0209/2013- 2012/2297 (INI)) http://www.europarl.europa.eu/si des/getDoc.do?pubRef=-//EP//TEXT+REPORT+A7-2013-0209+0+DOC+XML $+\mathrm{VO} / / \mathrm{IT}$.

European Parliament (2017). Resolution of 14 September 2017 on a new skills agenda for Europe (2017/2002(INI)) quote, 14 September 2017.

Eurostat (2001), Input-output Manual.

Fagnoni, S. \& A. Varesi (2015). 'Apprendistato: il nuovo quadro normativo dopo il testo unico ed i più recenti interventi legislativi' in DRI, 2015, n. 1, 15-181. 
Fagnoni, S. \& A. Varesi (2016), 'I contratti di apprendistato e la loro ulteriore differenziazione (artt. 41-47 d.lgs. 81/2015 e art. 32 d.lgs. 150/2015)' in M. Magnani, A. Pandolfo, P.A. varesi (eds.) I contratti di lavoro, Giappichelli, 2016, 185 ss.

ISTAT (2006), Le tavole delle risorse e degli impieghi e la loro trasformazione in tavole simmetriche. Nota metodologica, Ottobre 2006 per una descrizione metodologica delle citate tavole input-output.

Liguoro, L (2012), Che cosa è ECVET?Cì che è bene sapere sul Sistema europeo di crediti per l'istruzione e la formazione professionale, Formazione and Lavoro Focus 2/2012 monografico 70.

Luciani, V. (2016), La riforma dell'apprendistato: rapporto con il contratto a tutele crescenti e "riordino" delle fonti di regolazione, WP CSDLE "Massimo D'Antona".IT - 301/2016.

Massagli, E. (2016), Alternanza formativa e apprendistato in Italia e in Europa, Studium.

Massagli, E. (2017), Dall'alternanza scuola-lavoro all'integrazione formative, adapt labour studies, e-Book series n. 66, ADAPT University Press.

Perulli, E. (2011). 'La valorizzazione delle competenze in impresa: note tratte da un'indagine di sfondo per valutare l'utilizzabilità del libretto formativo nei contesti aziendali', in M. Tiraboschi (2011) Il testo unico dell'apprendistato e le nuove regole sui tirocini. Commentario al decreto legislativo 14 settembre 2011, n. 167, e all'articolo 11 del decreto legge 13 agosto 2011, n. 138, convertito con modifiche nella legge 14 settembre 2011, $n$. 148, Giuffrè, Milano.

Quagli, A. (2008). Analisi gestionale dei porti turistici nella nautica da diporto. Il caso di Imperia, Franco Angeli.

Rogowski, R. (ed.) (2008). The European Social Model and Transitional Labour Markets - Law and Policy, Ashgate.

Rustico, L. \& M. Tiraboschi (2011). 'Standard professionali, standard formativi e certificazione delle competenze' in M. Tiraboschi (2011) Il testo unico dell'apprendistato e le nuove regole sui tirocini. Commentario al decreto legislativo 14 settembre 2011, $n$. 167, e all'articolo 11 del decreto legge 13 agosto 2011, $n$. 138, convertito con modifiche nella legge 14 settembre 2011, n. 148, Giuffrè, Milano.

Ryzha, I. (2015). 'L'apprendistato nell'Unione Europea' in M.A. Carbone, L. Carollo, S. Donà, F. Fargnoli, I. Ryzha, \& C. Serrapica (eds.) Il contratto di apprendistato nel d.lgs. 81/15, WP C.S.D.L.E.M. D'Antona.IT, 286/2015, 8 ss.

Schmid, G. (2011). 'Il lavoro non standard. Riflessioni nell'ottica dei mercati transizionali del lavoro', in DRI 1/2011, 1-36.

Schmid, G. \& B. Gazier (2002) (eds.), The Dynamics of Full Employment. Social Integration Through Transitional Labour Markets, Edward Elgar.

Schmid, G. (1998). Transitional Labour Markets: A New European Employment Strategy, Wissenschaftszentrum Berlin für Sozialforschung Discussion Paper, 1998, FS I 98206.

Tiraboschi, M. (2011) Il testo unico dell'apprendistato e le nuove regole sui tirocini. Commentario al decreto legislativo 14 settembre 2011, n. 167, e all'articolo 11 del decreto legge 13 agosto 2011, n. 138, convertito con modifiche nella legge 14 settembre 2011, n. 148, Giuffrè, Milano. 
